\title{
INTERAKSI KOMUNIKASI BERBASIS MEDIA PEMBELAJARAN \\ DALAM PROSES BELAJAR-MENGAJAR
}

Oleh: Unang Wahidin*

\begin{abstract}
Interaction of communication in the learning process is an attempt to hold educational interaction in the learning activities, so that learning objectives can be achieved effectively and efficiently. Communication is the process of learning educational rapport between teachers and students which built effective communication and influence each other in a state of feeling between them in order to provide an opportunity for students to achieve the expected. Several methods of learning communication interaction that can be used to develop educational learning behavior in a variety of events interaction. To set the method of interaction where appropriate, the teacher should first establish whether a method can be said to be good, there needs to reference that originates in the primary factor which determined that "goal" to be achieved. To overcome the barriers in the communication process of learning required a variety of tools and/or media that can serve as the means used to distribute messages. In classroom learning, facilities or amenities tool used to facilitate communication with the media learning called learning.
\end{abstract}

Kata kunci: Interaksi, Komunikasi, Pembelajaran.

\section{A. Pendahuluan}

Persyaratan mendasar aspek apa pun dari keterampilan manusia adalah komunikasi -saling tukar informasi, pandangan, gagasan, sikap, nilai, pertimbangan, dan lain sebagainya- antara dua orang atau lebih. Komunikasi merupakan peristiwa sosial yang terjadi ketika manusia berinteraksi dengan manusia lain. Dalam hubungan sosialnya manusia tidak bisa terlepas dari komunikasi. Karena itu, komunikasi merupakan suatu usaha yang dilakukan setiap individu untuk menjalin hubungan dengan orang lain. Tanpa komunikasi maka tidak ada interaksi antar manusia dan akibatnya tidak ada sama sekali keterampilan manusia. Manusia saling berkomunikasi dengan berbagai macam cara dan semua pendekatan dipraktekan untuk memastikan bahwa saling tukar informasi tersebut dilakukan dengan jelas dan efektif.

\section{B. Komunikasi dalam Perspektif Islam}

Allah 题 menciptakan manusia dengan salah satu fungsi dasarnya untuk berkomunikasi, hal ini sebagaimana firman Allah dalam al-Qur'an surat ar-Rahman ayat 1-4 yang berbunyi:

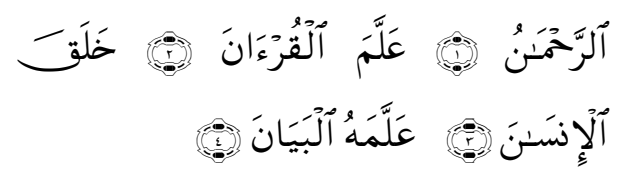

"Allah yang Maha Pemurah, yang telah mengajarkan al-Qur'an, Dia menciptakan manusia, mengajarnya pandai berbicara."

Tentang الْبَيَانَ (mengajarnya pandai berbicara), Al-Hasan mengatakan, "yang dimaksud dengan dengan al-bayan ialah pengujaran, yaitu membaca al-Qur'an. Pembacaan itu dengan memudahkan pengujaran kepada hamba-hamba-Nya dan memudahkan dalam mengartikulasikan huruf-huruf dari daerah-daerah artikulator, yaitu tenggorokan, lidah, dan bibir sesuai 
dengan keragaman artikulasi dan jenis huruf. ${ }^{1}$

Sedangkan dalam Tafsir Ibnu Katsir menjelaskan bahwa: Allah berfirman tentang karunia dan rahmat-Nya kepada hamba-hamba-Nya, bahwa Dia telah menurunkan Al-Qur'an kepada Muhmmad, Rasul-Nya, untuk disampaikan kepada semua hamba-Nya dan umat manusia yang berada di permukaan bumi ini. Dia telah mengajarkan Al-Qur'an dan memudahkan bagi hamba-Nya untuk menghafalkannya, memahaminya serta merenungkan hikmahhikmah dan pelajaran-pelajaran yang dikandungnya. Dia dan rahmat-Nya telah menciptakan manusia dan dibekali dengan kepandaian berkata dan berucap. ${ }^{2}$

Bila mengkaji isi al-Qur'an yang berhubungan dengan komunikasi, akan ditemukan ada sekian banyak term atau kata yang berhubungan dengan komunikasi. Di antara perkataan yang menerangkan aktifitas komunikasi dalam al-Qur'an yaitu:

1. Qara'a berarti membaca, terdapat dalam surat an-Nahl ayat 98 yang berbunyi:

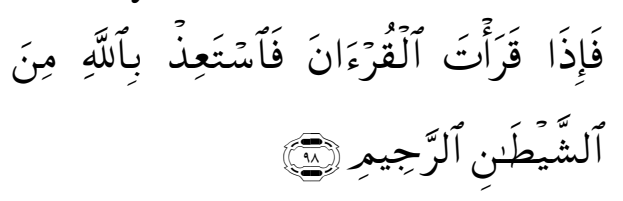

"Apabila kamu membaca AlQur'an hendaklah kamu meminta perlindungan kepada Allah dari syeitan yang terkutuk."

* Dosen Tetap Prodi. PAI Jurusan Tarbiyah STAI Al-Hidayah Bogor

1 Muhammad Nasib ar-Rifa'i. (2006). Terjemah Taisiru al-Aliyyul Qadir li Ikhtishari Tafsir Ibnu Katsir. Jakarta: Gema Insan, hlm. 540

2 H. Salim Bahreisy dan H. Salim Bahreisy. (1992). Terjamah Singkat Tafsir Ibnu Katsier Jilid VII. Surabaya: PT. Bina Ilmu, hlm. 392

2. Baligh berarti menyampaikan, terdapat dalam surat al-Maidah ayat 67 yang berbunyi:

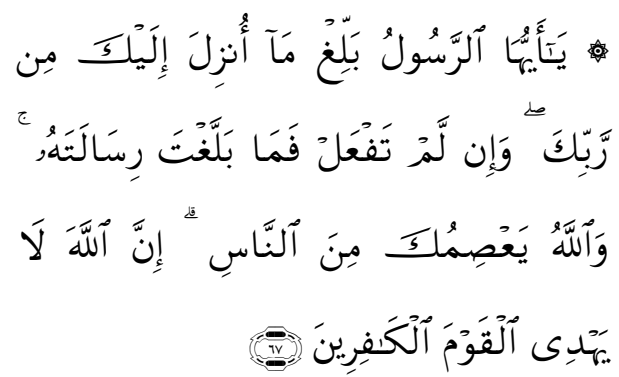

"Hai rasul, sampaikanlah apa yang diturunkan kepadamu dari Tuhanmu. Dan jika tidak kamu kerjakan (apa yang diperintahkan itu, berarti) kamu tidak menyampaikan amanat-Nya. Allah memelihara kamu dari (gangguan) manusia. Sesungguhnya Allah tidak memberi petunjuk kepada orang-orang yang kafir."

3. Basyhsyir berarti kabarkan, terdapat dalam surat an-Nisa' ayat 138 yang berbunyi:

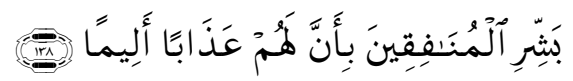

"Kabarkanlah kepada orangorang munafik bahwa mereka akan mendapat siksaan yang pedih."

4. Qul berarti katakan, terdapat dalam surat al-Ikhlash ayat 1 yang berbunyi:

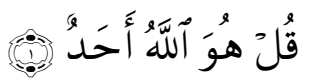

"Katakanlah: "Dia-lah Allah, yang Maha Esa."

5. $D a^{\prime} a$ berarti menyeru, terdapat dalam surat ali-Imran ayat 104 yang berbunyi:

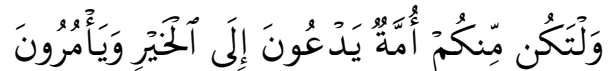

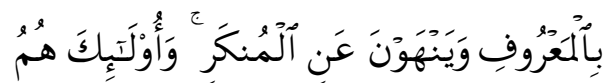

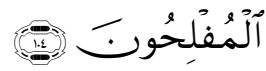

"Dan hendaklah ada di antara kalian segolongan umat yang menyeru kepada kebajikan, menyuruh kepada yang ma'ruf dan 
mencegah dari yang munkar; merekalah orang-orang yang beruntung."

6. Tawashau berarti berpesan-pesan, terdapat dalam surat al-Ashr ayat 3 yang berbunyi:

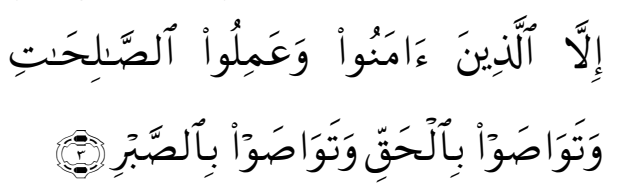

"Kecuali orang-orang yang beriman dan mengerjakan amal saleh dan nasehat menasehati supaya menaati kebenaran dan nasehat menasehati supaya menetapi kesabaran.'

7. Sa'ala berarti bertanya, terdapat dalam surat al-Maidah ayat 4 yang berbunyi:

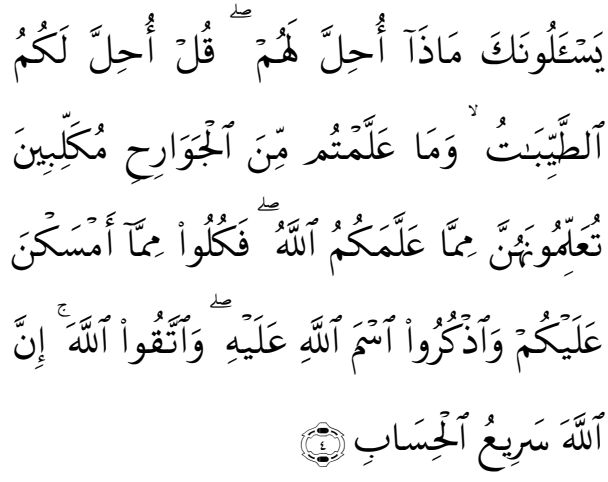

"Mereka menanyakan kepadamu:

"Apakah yang dihalalkan bagi mereka?". Katakanlah: "Dihalalkan bagi kalian yang baik-baik dan (buruan yang ditangkap) oleh binatang buas yang telah kalian ajar dengan melatih nya untuk berburu; kalian mengajarnya menurut apa yang telah diajarkan Allah kepada kalian. Maka makanlah dari apa yang ditangkapnya untuk kalian, dan sebutlah nama Allah atas binatang buas itu (waktu melepaskannya dan bertakwalah kepada Allah, Sesungguhnya Allah amat cepat hisab-Nya."
Masih banyak lagi term-term lain yang berkaitan dengan komunikasi yang bisa digali lebih jauh dalam al-Qur'an.

\section{Komunikasi}

\section{Pengertian Komunikasi}

Secara bahasa komunikasi berasal dari bahasa Latin, yaitu communication, yang berarti pemberitahuan, pemberian bagian (dalam sesuatu), pertukaran, di mana si pembicara mengharapkan pertimbangan atau jawaban dari pendengarnya. Kata sifatnya adalah communis, artinya bersifat umum atau bersama-sama. Kata kerjanya adalah communicare, artinya berdialog, berunding, atau musyawarah ${ }^{3}$.

Sedangkan secara istilah komunikasi adalah proses penyampaian pesan dari penyampai pesan (komunikator) kepada komunikan (penerima pesan) dengan tujuan tertentu ${ }^{4}$. Sedangkan menurut Adler dan Rodman $^{5}$ yang menyebut komunikasi sebagai, "...proses manusia merespons perilaku simbolik orang lain". Ada juga yang memandang komunikasi sebagai interaksi, di antaranya adalah Mulyana ${ }^{6}$ menjelaskan, mereka yang memandang komunikasi sebagai interaksi "menyetarakan komunikasi dengan suatu proses sebab akibat atau reaksi-reaksi, yang arahnya bergantian".

Dari beberapa pengertian tersebut di atas dapat disimpulkan bahwa pengertian komunikasi adalah proses penyampaian pesan dari sumber pesan kepada penerima

3 Daryanto. (2011). Ilmu Komunikasi. Bandung: Sarana Tutorial Nurani Sejahtera. hlm: 57.

4 Yosal Iriantara dan Usep Syaripudin. ( 2013). Komunikasi Pendidikan. Bandung: Simbiosa Rekatama Media. hlm: 6.

5 Adler, R. B., and G. Rodman. (2006). Understanding Human Communication. $9^{\text {th }}$ ed. Oxford: Oxford University Press. hlm. 4

6 D. Mulyana. (2005). Ilmu Komunikasi Suatu Pengantar. Bandung: Remaja Rosdakarya. hlm: 65. 
pesan melalui media tertentu dengan harapan pesan yang disampaikan sumber pesan bisa diterima oleh penerima pesan dan terjadi umpan balik.

Secara sederhana komunikasi dapat dipahami sebagai suatu proses atau aliran mengenai suatu pesan atau informasi yang bergerak dari suatu sumber pengirim (komunikator) hingga penerima (komunikan) dan berlangsung dinamis. Komunikasi adalah proses penyampaian ide dari pengirim (komunikator) kepada penerima (komunikan). Pesan dapat berupa pikiran, perasaan atau gambaran. Tujuannya adalah merubah, menambah atau memperbaiki pengetahuan, sikap atau tingkah laku si penerima pesan. Artinya melalui komunikasi si pengirim ide mengharapkan adanya perubahan kearah kesamaan pemahaman atau paling tidak pemahaman si pengirim pesan dipahami si penerima pesan. ${ }^{7}$

Komunikasi berbicara tentang cara menyampaikan dan menerima pikiranpikiran, informasi, perasaan, dan bahkan emosi seseorang, sampai pada titik tercapainya pengertian yang sama antara penyampai pesan dan penerima pesan. Human communication is the process through which individuals -in relationships, group, organizations and societies- respond to and create messages to adapt to the environment and one another (bahwa komunikasi manusia adalah proses yang melibatkan individuindividu dalam suatu hubungan, kelompok, organisasi dan masyarakat yang merespon

Sanusi Uwes. (2003). Visi dan Pondasi Pendidikan (Dalam Perspektif Islam). Jakarta: Logos. hlm. 153. dan menciptakan pesan untuk beradaptasi dengan lingkungan satu sama lain). ${ }^{8}$

\section{Kepentingan Komunikasi dalam Kehidupan}

Yosal Iriantara dan Usep Syaripudin mengatakan bahwa alasan manusia berkomunikasi karena: pertama, manusia tidak bisa hidup sendiri. Manusia membutuhkan kehadiran orang lain; dan kedua, manusia berkomunikasi dengan orang lain untuk menyampaikan pikiran, gagasan atau perasaannya. Informasi atau pesan (message) dipertukarkan di antara sesamanya. ${ }^{9}$ Cassagranda dalam Alo Liliweri $^{10}$ mengemukakan bahwa manusia berkomunikasi karena memerlukan orang lain untuk saling mengisi kekurangan dan membagi kelebihan, ingin terlibat dalam proses yang relatif tetap dan ingin menciptakan hubungan baru, setiap melakukan komunikasi bukan hanya menyampaikan isi pesan tetapi juga menentukan hubungan antar manusia.

Komunikasi telah diteliti secara sistematis sejak zaman dahulu (John Stewart, 1995: 33-101; W. Barnett Pearce and Karen A. Foss, 1990: 1-20; Nancy Harper, 1979), tetapi hal ini menjadi sebuah topik yang sangat penting pada abad ke-20. W. Barnett Pearce dalam Stephen W. Littlejohn dan Karen A. Foss 11 menggambarkan perkembangan ini sebagai sebuah "penemuan revolusioner" yang

8 Sasa Djuarsa Sendjaja dalam Olivia N.E. Maringka. "Efektivitas Komunikasi Keluarga Pada Anak-Anak Penggelut Dunia Modeling. (Studi Pada Masyarakat Di Kelurahan Bahu)". Journal "Acta Diurna” Vol. I No. I Th. 2013.

9 Iriantara dan Syaripudin. Komunikasi Pendidikan. hlm. 5.

10 Alo Liliweri. (1997). Komunikasi Antar Pribadi. Bandung: Citra Aditya. hlm. 45.

11 Stephen W. Littlejohn dan Karen A. Foss. (2011). Teori Komunikasi. Jakarta: Salemba Humanika. Edisi 9. hlm. 5-6. 
sebagian besar disebabkan oleh meningkatnya teknologi-teknologi komunikasi (seperti radio, televisi, telepon, satelit, dan jaringan komputer), bisnis besar, dan politik global. Sangat jelas bahwa komunikasi telah mengambil posisi penting dalam kehidupan manusia.

Becker dan Eckdom dalam Emanuel $^{12}$ mengindikasikan bahwa beberapa keterampilan berkomunikasi lebih penting untuk keberhasilan pekerjaan dibandingkan dengan keterampilan teknis tertentu. Sedangkan Harrel dan Harrel dalam Emanuel ${ }^{13}$ mengatakan bahwa tidak ada keahlian yang lebih penting untuk karir yang sukses dalam bisnis dari pada komunikasi yang baik.

Selanjutnya Ruben dan De Angelis dalam Utama, Suprapti, Wartini N. dan Widyatmika mengelompokkan kompetensi yang dibutuhkan oleh seseorang agar sukses dalam meniti karir dan dalam kehidupannya meliputi kompetensi personal, komunikasi, organisasi internasional atau antar budaya dan dominan. $^{14}$ Kompetensi berkomunikasi merupakan salah satu soft skill yang perlu dikembangkan. Elemen dari kompetensi berkomunikasi yang harus dimiliki diantaranya adalah: Pertama, kemampuan untuk dapat memberikan ide dengan jelas, efektif dan dengan keyakinan baik secara lisan maupun tertulis; Kedua, kemampuan

12 R. Emanuel. 2005). A Rationale for the Basic Course: Fundamentals of Oral Communication vs. Public Speaking. USA: Alabama State University.

13 R. Emanuel. (2005). A Rationale for the Basic Course: Fundamentals of Oral Communication vs. Public Speaking. USA: Alabama State University.

14 Utama, Suprapti, Wartini, N. dan Widyatmika. (2005). Konsep Pengembangan Panduan Evaluasi Pengembangan Soft Skills Mahasiswa Melalui Proses Pembelajaran di Univarsitas Udayana. Tim PHK-I Universitas Udayana. untuk melihat pesan non verbal; Ketiga, kemampuan untuk memperaktekan keterampilan mendengarkan aktif dan kemampuan untuk merespon dengan baik; dan Keempat, kemampuan untuk presentasi dengan jelas dan dapat meyakinkan audience. ${ }^{15}$

Berdasarkan paparan tersebut di atas mengindikasikan bahwa kompetensi komunikasi yang dimiliki seseorang menjadi modal dalam meniti karir, pekerjaan dan menjalin hubungan dengan orang lain baik untuk saat ini maupun untuk masa depan. Terlebih saat ini perkembangan teknologi komunikasi semakin pesat sehingga kompetensi komunikasi yang menjadi alat hubungan antar individu dan kelompok baik dalam lingkup lokal, regional maupun internasional semakin menjadi kebutuhan yang mendesak.

\section{Komunikasi Pembelajaran}

\section{Pengertian Komunikasi Pembelajaran}

Pengertian komunikasi pembelajaran dirumuskan Richmond et.al. ${ }^{16}$ sebagai proses dimana guru membangun relasi komunikasi yang efektif dan afektif dengan siswa sehingga siswa berkesempatan meraih keberhasilan yang maksimal dalam proses pembelajaran. Relasi yang dimaksud adalah hubungan ${ }^{17}$, sedangkan efektif adalah dapat membawa hasil; berhasil

15 Sharma. (2009). Importance of Soft Skills Development in Education. Diakses dari http:// schoolo feducators.com/2009/02/importance-ofsoft-skills-development-in-education/diakses pada 6 April 2013.

16 Richmond, P. V., J. S Wrench, and J. Gorhan. (2009). Communication. Affect. and Learning in the Classroom. California: Creative Common. Page 1.

17 Kamus Besar Bahasa Indonesia. (2012). Pusat Bahasa. Cetakan Keempat. Edisi Keempat. Jakarta: Departemen Pendidikan Nasional. Gramedia. hlm: 1159. 
guna $^{18}$ dan afektif adalah mempengaruhi keadaan perasaan dan emosi ${ }^{19}$.

Dari pengertian tersebut di atas dapat dirumuskan pengertian komunikasi pembelajaran adalah proses terjadinya jalinan hubungan edukatif antara guru dengan siswa dimana komunikasi yang dibangun berhasil guna dan saling mempengaruhi keadaan perasaan di antara mereka dalam rangka memberi kesempatan kepada siswa untuk mencapai prestasi yang diharapkan.

Tujuan membangun komunikasi efektif dan afektif adalah mewujudkan kegiatan pembelajaran yang dapat memfasilitasi peserta didik mencapai tujuan pembelajaran. Komunikasi yang efektif artinya guru dan peserta didik sama-sama memahami apa yang dikomunikasikan dan bagaimana mengkomunikasikannya. Selain itu, guru dan peserta didik saling memahami sejauh mana kinerjanya dalam pembelajaran. Sedangkan komunikasi afektif bertujuan membangun keadaan saling memahami perasaan antara guru dan siswa terhadap proses komunikasi dan apa yang sedang dibelajarkan. ${ }^{20}$

Dalam komunikasi pembelajaran, guru memainkan peran sebagai pengatur dan pengarah alur aktivitas. Selain harus membekali diri dengan pengetahuan yang memadai tentang isi pembelajaran yang akan disajikan dan metode penyampaiannya, guru juga harus memiliki kemampuan dalam mendesain komunikasi efektif dengan peserta didik. Kemampuan ini sangat penting karena berdampak

18 Kamus Besar Bahasa Indonesia. (2012). hlm. 352.

19 Kamus Besar Bahasa Indonesia. ( 2012). hlm:14.

20 Yosal Iriantara dan Usep Syaripudin. (2013). Komunikasi Pendidikan. hlm. 74. langsung pada kualitas pemahaman peserta didik akan materi yang diajarkan.

\section{Beberapa Masalah dalam Komunikasi Pembelajaran}

Beberapa masalah yang biasanya dihadapi guru dalam menggunakan komunikasi pembelajaran di antaranya adalah:

a. Guru kurang memperhatikan situasi ketika komunikasi pembelajaran sedang dilangsungkan dalam proses pembelajaran, padahal situasi akan sangat berpengaruh terhadap proses komunikasi dalam pembelajaran. Hal ini sebagaimana disampaikan oleh Anne Ahira ${ }^{21}$, yang menyatakan bahwa seorang komunikator harus mampu memperhatikan situasi ketika komunikasi sedang dilangsungkan, sebab situasi akan sangat berpengaruh terhadap proses komunikasi terutama pada faktor sosiologis, antropologis, dan psikologis.

b. Pada saat proses komunikasi pembelajaran berlangsung terjadi hambatan menyangkut bahasa yang digunakan sebagai alat penyampai pesan (materi pelajaran). Menurut Anne Ahira, ${ }^{22}$ gangguan ini disebut hambatan semantis, yaitu hambatan yang terjadi di dalam diri komunikator (guru), yaitu menyangkut bahasa yang digunakan sebagai alat penyampai pesannya. Gangguan semantis bisa menyebabkan salah tafsir yang pada akhirnya akan mengakibatkan salah komunikasi.

21 Anne Ahira. (2013). Faktor-Faktor Penghambat Komunikasi Efektif. Tersedia: (on-line). http://www. anneahira.com/komunikasiefektif.htm.24 Maret 2013. pkl.12.23 AM.

22 Anne Ahira. (2013). Faktor-Faktor Penghambat Komunikasi Efektif. Tersedia: (on-line). http://www. anneahira.com/komunikasiefektif.htm.24 Maret 2013. pkl.12.23 AM. 
Komunikan (peserta didik) akan mengambil inisiatif sesuai dengan apa yang diduga yang belum tentu sesuai dengan maksud komunikator. Seharusnya, komunikasi semantis harus jelas dan tegas dengan memilih kalimat-kalimat yang mengandung persepsi yang jelas dengan susunan kalimat yang logis.

c. Terjadi hambatan mekanis, yaitu hambatan yang banyak dijumpai pada waktu guru menggunakan alat bantu mengajar atau media pembelajaran yang akan digunakan dalam proses komunikasi pembelajaran. Misal: papan tulis dalam keadaan tidak bersih dari tulisan materi pelajaran sebelumnya, dan bila guru menggunakan media pembelajaran yang berjenis elektronik perlu waktu untuk mempersiapkannya sehingga menyita waktu pelajaran yang tersedia.

d. Terjadi hambatan ekologis, yaitu hambatan yang disebabkan oleh lingkungan dimana proses komunikasi pembelajaran sedang dilangsungkan. Kasus yang sering terjadi adalah suara kendaraan yang melalui jalan yang dekat dengan bangunan sekolah.

e. Permasalahan lain yang dihadapi guru adalah dalam menyusun katakata dengan baik ketika berbicara dengan peserta didik dan mampu berbicara langsung kepada inti. Menurut Johar Permana, ${ }^{23}$ keterampilan verbal dalam berbicara (lisan) merupakan kemampuan mengekspresikan bahan pembicaraan dalam bahasa kata-kata. Dalam komunikasi gunakanlah kata-kata yang pendek, sederhana, dan langsung pada sasaran (keep language short, simple and to the point).

f. Selain itu terlihat adanya permasalahan pada kompetensi komunikasi pembelajaran guru dalam proses pembelajaran. Di mana komunikasi antar pribadi kurang berjalan baik, karena masih terjadi perbedaan makna dan perbedaan pemahaman dari apa yang dikomunikasikan antara guru dengan peserta didik, hal ini mengakibatkan umpan balik jarang terjadi. Sedangkan komunikasi antar pribadi, merupakan suatu proses komunikasi yang terjadi antara dua orang atau lebih yang saling bertukar pesan dengan tujuan untuk berbagi makna, menciptakan pemahaman dan mengembangkan hubungan. Hal ini sebagaimana dikatakan oleh Bochner, Cappela, Miler, De Vito dalam Dita S.N.A. Diliani ${ }^{24}$, tentang komunikasi antar pribadi, yaitu komunikasi dengan mengamati komponenkomponen utamanya, dalam hal ini penyampaian pesan oleh satu orang dan penerimaan pesan oleh orang lain atau sekelompok kecil orang, dengan berbagai dampaknya dan dengan peluang untuk memberikan umpan balik dengan segera.
23 Johar Permana. (2013). Teknik Komunikasi Dalam Pelatihan, Diakses dari UPI.edu/Direktori/FIP/Jur. Administrasi Pendidikan. Tersedia: (on-line). 24 Maret 2013, pkl. 13.40 .
24 Dita S.N.A. Diliani. (2002). Kompetensi Komunikasi Guru Taman kanak-Kanak. (Tesis). Fakultas Ilmu Sosial dan Ilmu Politik. Pascasarjana Universitas Indonesia. 


\section{Komponen-Komponen Komunikasi Pembelajaran}

Dalam proses pembelajaran, komponen proses komunikasi pembelajaran pada prinsipnya sama dengan komponen proses komunikasi. Hal ini sebagaimana yang disampaikan Arief S. Sadiman yaitu terdiri dari: pesan, sumber pesan, saluran atau media, dan penerima pesan. Artinya pada proses pembelajaran telah menjalankan fungsi komunikasi tersebut. ${ }^{25}$ Sedangkan menurut Tim Dosen FIP IKIP Yogyakarta, ${ }^{26}$ komponen komunikasi yang terdapat dalam pembelajaran sebagai komunikasi adalah: a. pengajar/guru dapat menjalankan fungsinya sebagai pemberi pesan (komunikator); b. pembelajar/siswa sebagai penerima pesan (komunikan); c. materi pelajaran sebagai pesan; d. alat bantu sebagai saluran atau media pembelajaran; dan e. ada faktor lain dalam pembelajaran adalah umpan balik yang manifestasinya berupa pertanyaan, jawaban, dan persilangan pendapat, baik dari pembelajar maupun dari pengajar.

Apabila proses pembelajaran adalah proses komunikasi, maka menurut Arief S. Sadiman $^{27}:$ a. Pesan yang akan dikomunikasikan adalah isi pelajaran yang terdapat dalam kurikulum; b. Sumber pesan (encoder), dapat saja pengajar, pembelajar, penulis buku, ataupun orang lain. Pada posisi ini pembelajar dapat saja sebagai sumber pesan dalam proses pembelajaran

25 Arief S. Sadiman. (1990). Media Pendidikan. Pengertian. Pengembangan. dan Pemanfaatannya. Jakarta: Raja Grafindo Persada. hlm. 11.

26 Tim Dosen FIP IKIP Yogyakarta. (1992). Bacaan Wajib Media Pembelajaran, Diktat, FIP IKIP. Yogyakarta. hlm. 3.

27 Arief S. Sadiman. (1990). Media Pendidikan. Pengertian. Pengembangan. dan Pemanfaatannya. Jakarta: Raja Grafindo Persada. hlm. 12. dan pengajar dapat menerima informasi dari pembelajar. Komunikasi yang terjadi adalah komunikasi timbal balik dan posisi pengajar tentu saja sebagai penerima pesan; c. Penerima pesan (decoder) adalah pembelajar. Dalam proses belajar dapat saja pembelajar sebagai penerima pesan dan juga sebagai pemberi pesan kepada pengajar; dan d. Saluran yang digunakan. Selanjutnya Daryanto ${ }^{28}$ mengatakan bahwa dalam pembelajaran dapat menggunakan alat-alat bantu pembelajaran atau media pembelajaran, yang disebut dalam komponen komunikasi adalah saluran dan umpan balik (feed back) dari penerima pesan (decoder) kepada pemberi pesan (encoder), dan sebaliknya.

Sedangkan menurut Sri Anitah Wiryawan dan Noorhadi Th. ${ }^{29}$ bahwa komponen-komponen yang terdapat dalam suatu proses komunikasi pembelajaran, adalah:

a. Konteks. Konteks dapat diartikan mendekati pengertian setting atau situasi. Artinya peristiwa komunikasi selalu terjadi pada suatu lingkungan tertentu. Di mana setiap konteks dalam komunikasi dapat dilihat dalam dimensi fisik, sosial, dan kebudayaan.

b. Pengirim (Komunikator). Pengirim (komunikator) merupakan sumber dari suatu pesan. Pengirim (komunikator) inilah disamping sebagai penghasil pesan (sumber) juga sebagai pengirim pesan. Untuk dapat melaksanakan komunikasi dengan efektif terdapat dua faktor penting yang harus dimiliki guru

28 Daryanto. (2011). Ilmu Komunikasi. hlm. 58.

29 Sri Anitah Wiryawan dan Noorhadi Th. (1994). Strategi Belajar Mengajar. Universitas Terbuka. hlm. 4-9. 
sebagai komunikator, yakni kepercayaan pada komunikator (source credibility) dan daya tarik komunikator (source attractiveness). Kepercayaan kepada komunikator/guru ditentukan oleh keahlian dan dapat tidaknya dipercaya. Komunikator/guru akan mempunyai kemampuan untuk melakukan perubahan sikap melalui mekanisme daya tarik, jika pihak komunikan/siswa merasa bahwa komunikator/guru ikut serta dengan mereka dalam hubungannya dengan opini secara memuaskan.

c. Pesan. Pesan dalam peristiwa belajar mengajar berupa ajaran atau informasi yang berbentuk ide, fakta, konsep, prosedur, data dan sebagainya. Pesan-pesan yang dikirim guru harus dapat dimengerti dan dipahami oleh si penerima pesan (siswa), baik dalam bentuk verbal aupun non verbal.

d. Sistem Penyampaian. Sistem penyampaian ini berkaitan dengan metode dan media. Guru tidak saja dituntut untuk mengetahui berbagai metode secara konseptual teoritik, tetapi guru harus mampu dan terampil dalam memilih dan menggunakan metode yang sesuai dengan pesan yang disampaikan, siswa yang menerima pesan, dan tujuan pembelajaran. Keberhasilan proses belajar sangat tergantung dari semua indera yang dimiliki siswa itu sendiri, meskipun media itu dapat dipakai secara baik melalui indera pendengaran dan penglihatan. Dengan demikian media yang digunakan dalam kegiatan pembelajaran hendaknya mencakup semua objek yang menarik semua indera. e. Penerima/Komunikan. Siswa dalam hubungan proses komunikasi berkedudukan sebagai penerima pesan. Kegiatan pembelajaran merupakan kegiatan yang dilandasi oleh pemikiran yang bermuara pada siswa. Pandangan terhadap kedudukan siswa dalam proses komunikasi, demikian juga dalam proses belajar mengajar akan menghasilkan satu bentuk atau pola komunikasi tertentu. Dilihat dari komponen penerima/komunikan atau siswa, seseorang dapat dan akan menerima sebuah pesan hanya kalau terdapat empat kondisi berikut: 1) penerima/komunikan/siswa benarbenar mengerti pesan yang disampaikan oleh komunikator/guru; 2) pada saat penerima/komunikan/siswa mengambil keputusan, ia sadar bahwa keputusannya itu sesuai dengan tujuannya; 3) pada saat ia mengambil keputusan, ia sadar bahwa keputusannya itu bersangkutan dengan kepentingan pribadinya; dan 4) ia mampu untuk menempatinya baik secara mental maupun fisik.

\section{Model-Model Interaksi Komunikasi dalam Proses Pembelajaran}

Richmond et.al. ${ }^{30}$ mengatakan bahwa interaksi guru dan siswa di kelas adalah komunikasi pembelajaran (instructuional communication). Sebagai gambaran bagaimana terjadinya interaksi komunikasi antara guru - siswa dalam proses pembelajaran, berikut ini dikemukakan visualisasinya dalam bentuk diagram $^{31}$ :

\footnotetext{
30 Richmond, P. V., J. S Wrench, and J. Gorhan. (2009). Communication. Affect. and Learning in the Classroom. California: Creative Common.

31 Wiryawan dan Noorhadi, Strategi Belajar Mengajar hlm: 33-35.
} 
Pertama: Pada situasi dimana hanya guru yang berbicara, tanpa memberi kesempatan kepada siswa untuk bertanya, berkomentar atau pun mengajukan pendapat, maka komunikasi hanya berlangsung satu arah. Situasi ini dilukiskan dalam diagram berikut ini:

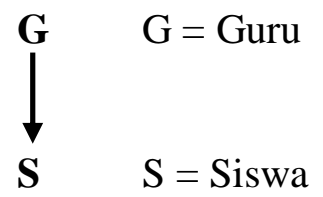

Kedua, Pada situasi dimana siswa yang belajar atau anggota suatu kelompok belajar, aktif mengajukan pertanyaan atau menyumbangkan gagasan, maka komunikasi yang berlangsung adalah komunikasi dua arah. Setiap orang diperkenankan dan didorong untuk secara lisan berinteraksi terhadap apa yang dikemukakan. Pola interaksi ini dilukiskan dalam diagram berikut ini:

$$
\begin{array}{ll}
\mathbf{G} & \mathrm{G}=\text { Guru } \\
\mathbf{S} & \mathrm{S}=\text { Siswa }
\end{array}
$$

Ketiga, Jika anggota kelompok belajar atau siswa bebas mengajukan pertanyaan, komentar, atau pendapat kepada anggota atau siswa lainnya seperti halnya kepada guru, maka tanda panah dalam komunikasi yang berlangsung yang menghubungkan secara anggota dan juga kepada guru.

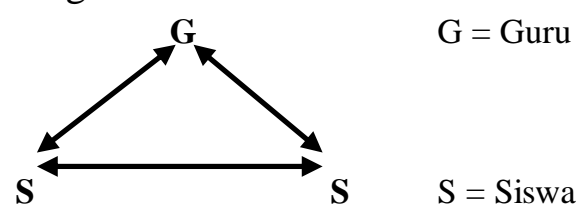

\section{Hubungan Interaksi komunikasi dengan Metode dalam Proses Pembelajaran}

Banyak metode interaksi komunikasi yang dapat digunakan untuk membina tingkah laku belajar secara edukatif dalam berbagai peristiwa interaksi. Untuk menetapkan metode interaksi mana yang tepat, guru harus menetapkan lebih dahulu apakah sebuah metode dapat dikatakan baik, diperlukan adanya acuan yang bersumber pada faktor utama yang menentukannya yaitu "tujuan" yang akan dicapai.

Penggunaan metode interaksi komunikasi dalam proses belajar mengajar merupakan upaya untuk mengadakan interaksi edukatif dalam kegiatan pembelajaran, sehingga tujuan pembelajaran dapat tercapai dengan efektif dan efisien. Untuk dapat mencapai tujuan tersebut, guru harus melakukan penghampiran terhadap bentuk kegiatan interaksi, seperti: a. penyampaian informasi; b. penciptaan dialog; c. peningkatan keterampilan; d. penetapan musyawarah; e. pemantapan pengalaman; $f$. pengujian kemahiran; g. perluasan cakrawala; dan h. pemupukan kegotongroyongan. ${ }^{32}$ Berdasarkan atas berbagai arah interaksi komunikasi dalam hubungannya dengan metode dalam proses pembelajaran, berikut ini disajikan diagram yang menggambarkan interaksi komunikasi dari masing-masing metode pembelajaran: ${ }^{33}$

\footnotetext{
32 Anitah Wiryawan dan Noorhadi. Strategi Belajar Mengajar. hlm: 34

33 Ibid., hlm: 34-35.
} 
a. Interaksi Komunikasi Metode Pembelajaran

Ceramah

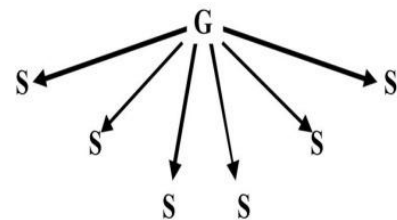

$\mathrm{G}=$ Guru

$\mathrm{S}=$ Siswa

b. Interaksi Komunikasi Metode Pembelajaran Tanya Jawab \& Metode Pembelajaran Tanya Jawab Forum
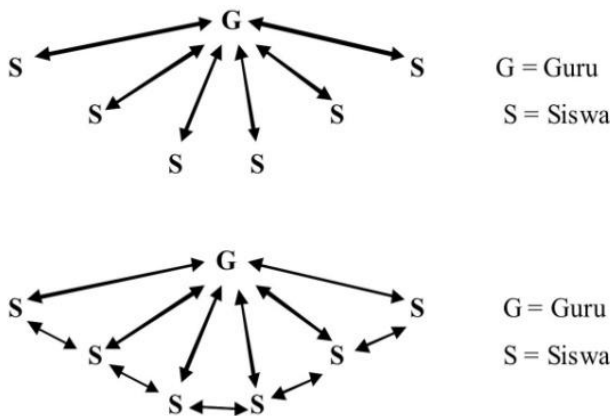

$\mathrm{G}=\mathrm{Guru}$

$\mathrm{S}=$ Siswa

c. Interaksi Komunikasi

Pembelajaran Diskusi

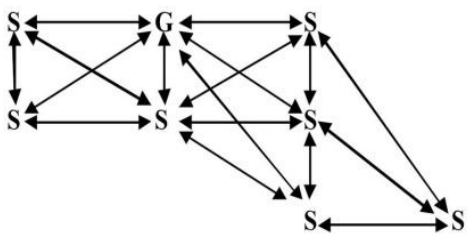

d. Interaksi Komunikasi Metode Pembelajaranan Latihan

S $\longrightarrow$ Latihan I- - - - $\rightarrow$ Latihan IF - - - $>$ Latihan III

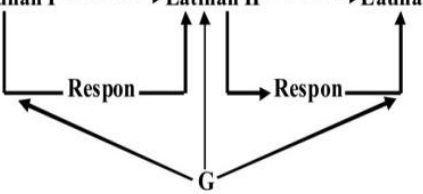

e. Interaksi Komunikasi Metode Pembelajaran Demonstrasi dan Eksperimen

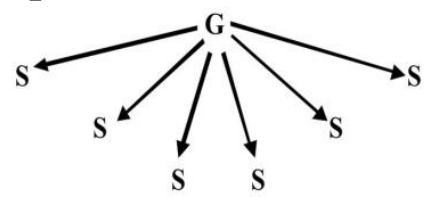

$\mathrm{G}=\mathrm{Guru}$

Eksperimen

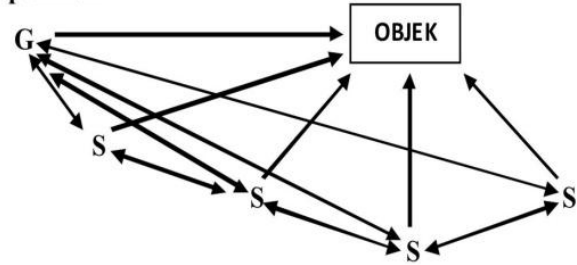

f. Interaksi Komunikasi Metode Pembelajaran Kerja/Tugas

Individual dan Kelompok

Individual

Kelompok
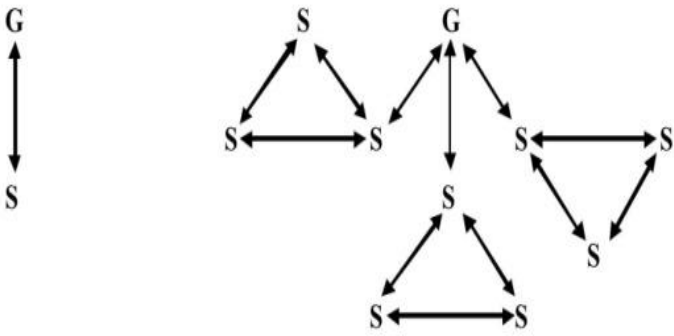

g. Interaksi Komunikasi Metode Pembelajaran Karya Wisata

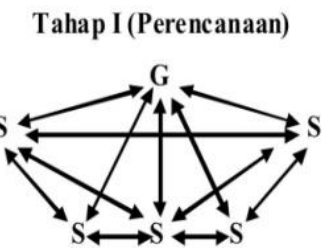

Tahap II (Pelaksanaan)

Tahap III

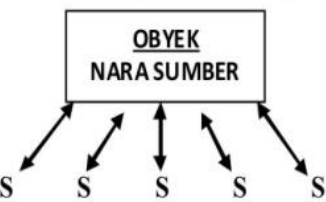

(Pelaporan/Evaluasi)

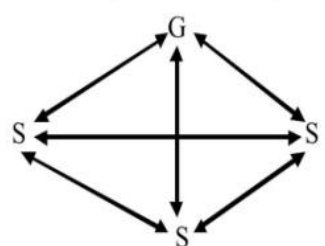

h. Interaksi Komunikasi Metode Pembelajaran Panel

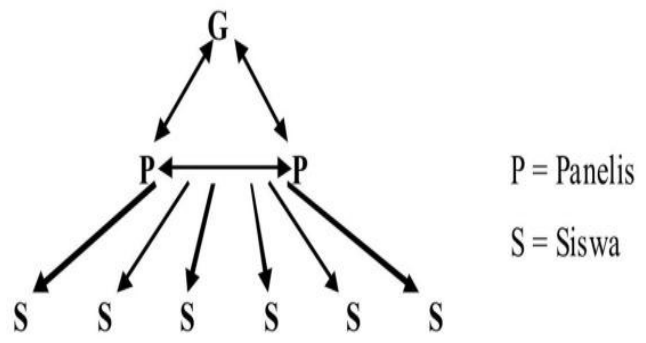

i. Interaksi Komunikasi Metode Pembelajaran Seminar

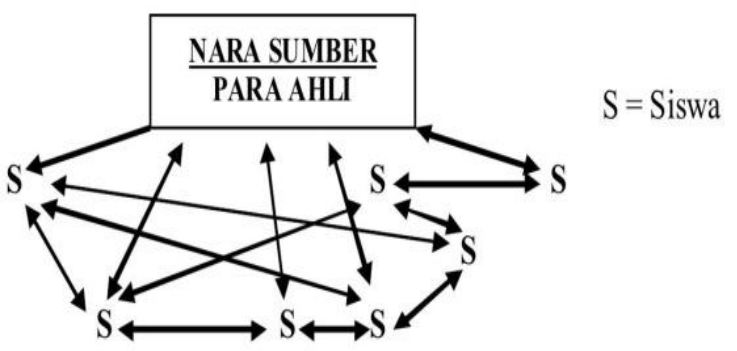


j. Interaksi Komunikasi Metode Pembelajaran Simposium

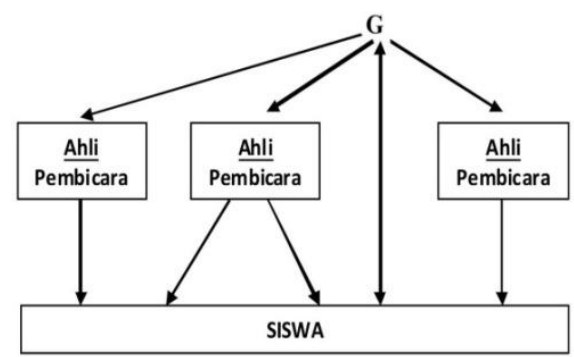

k. Interaksi Komunikasi Metode Pembelajaran Bermain Peran (Role Playing)

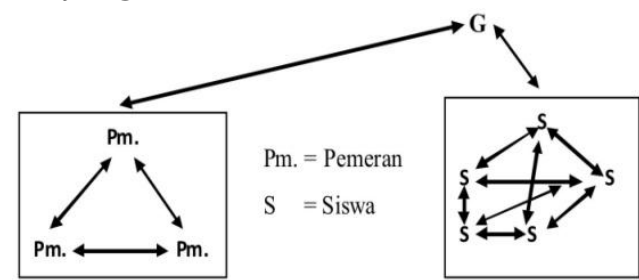

I. Interaksi Komunikasi Metode Pembelajaran Lokakarya

Langkah I

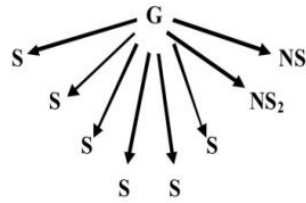

Langkah II
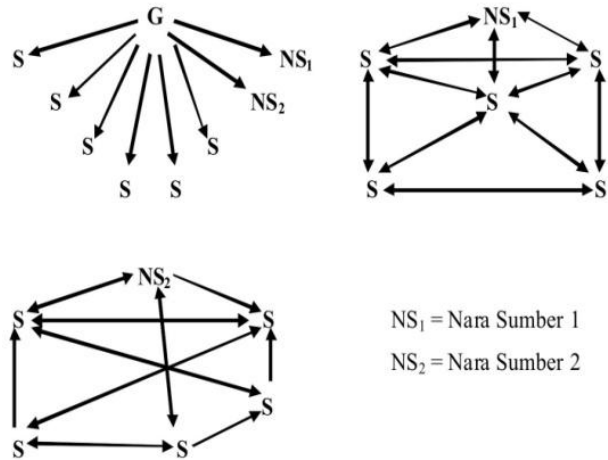

$\mathrm{NS}_{1}=$ Nara Sumber 1 $\mathrm{NS}_{2}=$ Nara Sumber 2

\section{Hambatan Proses Komunikasi dalam Pembelajaran}

Hambatan komunikasi sering disebut dengan "misscommunication" dapat disebabkan oleh beberapa faktor, antara lain sebagai berikut: ${ }^{34}$ a. Pengorganisasian informasi, ide, pesan, dan waktu yang kurang memadai; b. Kurangnya kerja sama (koordinasi) di antara unsur-unsur yang terlibat; c. Membiarkan terjadinya penyampaian pesan yang kurang jelas, samar-samar atau mempunyai makna lebih

34 Daryanto. Ilmu Komunikasi. hlm: 75-76.

dari satu sehingga menjadikan ketidakjelasan; d. Keberadaan tempat yang kurang nyaman, apakah terlalu panas atau suasana yang ribut; f. Kemungkinan salah media yang dipilih di dalam interaksi yang dilaksanakan; g. Kurangnya persiapan komunikator (pemberi pesan); h. Karena hambatan kesiapan penerima atau pemberi pesan; i. Karena hambatan emosional kedua belah pihak, baik pemberi pesan (komunikator) maupun penerima pesan (komunikan); j. Kesalahpahaman berkomunikasi, yang dapat disebabkan oleh beberapa hal, seperti pengiriman pesan, penyampaian pesan, penerimaan pesan, dan penafsiran pesan.

Selanjutnya Daryanto ${ }^{35}$ mengatakan, dalam proses komunikasi belajar mengajar, guru (komunikator) harus mampu menciptakan proses komunikasi yang efektif. Untuk itu, seorang guru (komunikator) harus melakukan prinsip dan konsep pendekatan komunikasi yang benar. Di samping itu, guru (komunikator) harus mampu meminimalkan faktor-faktor yang menyebabkan kegagalan komunikasi. Hal tersebut dapat dicapai jika proses pembelajaran dilakukan terus-menerus dan dinamis.

Sedangkan menurut Hujair AH. Sanaki $^{36}$, dalam proses pembelajaran ada beberapa faktor yang menjadi hambatan proses komunikasi atau dikenal dengan istilah barriers atau noises. Hambatanhambatan tersebut adalah:

a. Faktor internal. Hambatan yang berasal dari dalam diri penerima pesan atau pembelajar itu sendiri, berupa:

\footnotetext{
35 Ibid., hlm: 76.

36 Hujair AH. Sanaky. (2011). Media Pembelajaran: Buku Pegangan Wajib Guru dan Dosen. Yogyakarta: Kaukaba. hlm: 13.
} 
1) Hambatan psikologis, seperti minat, sikap, pendapat, kepercayaan, intelegensi, pengetahuan. Pembelajar yang senang terhadap mata pelajaran, topik, serta pengajarnya tentu lain hasil belajarnya dibandingkan dengan yang benci atau tak menyukai semua itu.

2) Hambatan fisik, seperti kelelahan, sakit, keterbatasan daya indera, dan cacat tubuh. Jangan terlalu banyak mengharapkan dari pembelajar yang lagi sakit karena pesan-pesan yang disampaikan padanya akan terhambat karenanya.

b. Hambatan eksternal. Hambatan yang berasal dari luar pembelajar, seperti:

1) Hambatan kultural, seperti perbedaan adat istiadat, norma-norma sosial, kepercayaan, dan nili-nilai panutan. Perbedaan adat istiadat, norma sosial, dan kepercayaan kadang-kadang dapat menjadi sumber salah paham.

2) Hambatan lingkungan, ${ }^{37}$ yaitu hambatan yang ditimbulkan oleh situasi dan kondisi keadaan sekitar. Proses pembelajaran di tempat yang tenang, sejuk, dan nyaman, tentu akan lain hasilnya dengan proses yang dilakukan di kelas yang bising, panas, dan berjubel.

Selanjutnya Hujair AH. Sanaki ${ }^{38}$ mengatakan, berbagai jenis hambatan tersebut di atas, baik pada diri pengajar maupun pada diri pembelajar, dapat mengakibatkan proses pembelajaran sering kali berlangsung tidak efektif untuk mencapai tujuan yang diinginkan. Maka

37 Sadiman. Media Pendidikan. Pengertian. Pengembangan. dan Pemanfaat-annya. hlm: 14.

38 Sanaky. Media Pembelajaran, Buku Pegangan Wajib Guru dan Dosen. hlm: 14. bagi pengajar perlu memperhatikan dan mengantisipasi hal-hal tersebut, sehingga berusaha untuk mengeliminasi atau bahkan menghilangkan sama sekali hambatanhambatan tersebut. Berbagai hambatan proses komunikasi dalam pembelajaran, baik dalam diri pengajar maupun pembelajar, baik sewaktu men-encode (proses penuangan pesan), maupun mendecode-nya (proses penafsiran), seringkali berlangsung secara tidak efektif atau kurang mencapai hasil yang diinginkan. Maka untuk mengatasi hambatan-hambatan tersebut, diperlukan berbagai alat dan atau media pembelajaran yang dapat berfungsi sebagai sarana yang digunakan untuk menyalurkan pesan.

Melalui proses komunikasi, pesan dapat diterima, diserap, dihayati penerima pesan, maka agar tidak terjadi kesalahan dalam proses komunikasi, perlu digunakan sarana yang dapat membantu proses komunikasi. Dalam pembelajaran di kelas, sarana/fasilitas alat yang digunakan untuk memperlancar komunikasi pembelajaran disebut dengan media pembelajaran. ${ }^{39}$

\section{E. Media dan Media Pembelajaran 1. Pengertian dan Batasan Media}

Kata media berasal dari bahasa Latin yaitu medius yang secara harfiah berarti 'tengah', 'perantara' atau 'pengantar ${ }^{\text {, }}$. Sedangkan Arief S. Sadiman et.al, ${ }^{41}$ mengatakan, kata media berasal dari bahasa Latin dan merupakan bentuk jamak dari kata medium yang secara harfiah berarti perantara atau pengantar. Sehingga media dapat dikatakan sebagai perantara atau

39 Sanaky. Media Pembelajaran, Buku Pegangan Wajib Guru dan Dosen. hlm: 9.

40 Azhar Arsyad. (2004). Media Pembelajaran. Jakarta: Raja Grafindo Persada. hlm. 3

41 Sadiman. Media Pendidikan. Pengertian. Pengembangan. dan Pemanfaatannya. hlm: 6. 
pengantar pesan dari pengirim ke penerima pesan. Selanjutnya Bovee dalam Ouda Teda Ena $^{42}$ mengatakan media adalah sebuah alat yang mempunyai fungsi menyampaikan pesan.

Berdasarkan beberapa pengertian di atas dapat dikatakan bahwa media adalah alat bantu yang dapat digunakan untuk menyalurkan pesan dari pengirim (komunikator) ke penerima pesan (komunikan) sehingga dapat merangsang pikiran, perasaan, perhatian, dan minat siswa sedemikian rupa sehingga proses belajar terjadi.

Banyak batasan pengertian media, di antaranya: ${ }^{43}$

a. Asosiasi Teknologi dan Komunikasi Pendidikan (Association of Education and Communication Technologi (AECT) di Amerika, membatasi media sebagai segala bentuk dan saluran yang digunakan orang untuk menyalurkan pesan/ informasi.

b. National Education Association (NEA), menyatakan bahwa "media" adalah bentuk-bentuk komunikasi baik tercetak maupun audio-visual serta peralatannya.

c. Gagne, menyatakan bahwa media adalah berbagai jenis komponen atau sumber belajar dalam lingkungan pembelajar yang dapat merangsang pembelajar untuk belajar.

d. Briggs, menyatakan media adalah segala wahana atau alat fisik yang dapat menyajikan pesan serta merangsang siswa untuk belajar.

42 Ouda Teda Ena. (2003). Membuat Media Pembelajaran Interaktif dengan Piranti Lunak Presentasi. From: http://www.ialf.edu/kipbipa /papers/ Ouda Teda Ena.doc, Akses, Senin, 20/10/2003.

43 Sadiman. Media Pendidikan. Pengertian. Pengembangan. dan Pemanfaatannya. hlm. 8

\section{Pengertian Media Pembelajaran}

Dalam proses belajar mengajar, media pembelajaran dijadikan saluran/alat penyampai pesan dari guru (komunikator) kepada siswa (komunikan). Hal ini sebagaimana yang disampaikan Hujair AH. Sanaky $^{44}$ bahwa media pembelajaran adalah sebuah alat yang berfungsi dan digunakan untuk menyampaikan pesan pembelajaran. Selanjutnya Hujair AH. Sanaky mengatakan bahwa substansi dari media pembelajaran adalah: a. Bentuk saluran, yang digunakan untuk menyalurkan pesan, informasi atau bahan pelajaran kepada penerima pesan atau pembelajar; b. Berbagai jenis komponen dalam lingkungan pembelajar yang dapat merangsang pembelajar untuk belajar; c. Bentuk alat fisik yang dapat menyajikan pesan serta merangsang pembelajar untuk belajar; d. Bentuk-bentuk komunikasi yang dapat merangsang pembelajar untuk belajar, baik cetak maupun audio, visual, dan audio visual.

Selain itu media pembelajaran adalah sarana pendidikan yang dapat digunakan sebagai perantara dalam proses pembelajaran untuk mempertinggi efektivitas dan efisiensi dalam mencapai tujuan pengajaran. Dalam pengertian lebih luas, media pembelajaran adalah alat, metode, dan teknik yang digunakan dalam rangka lebih mengefektifkan komunikasi dan interaksi antara pengajar dan pembelajar dalam proses pembelajaran di kelas ${ }^{45}$.
44 Sanaky. Media Pembelajaran, Buku Pegangan Wajib Guru dan Dosen. hlm: 3.

45 Oemar Hamalik. (1989). Media Pendidikan. Bandung: Citra Aditya Bakti. hlm. 12. 
Sedangkan Cecep Kustandi dan Bambang Sutjipto ${ }^{46}$ memberi kesimpulan dari peristilahan media pembelajaran sebagai berikut: a. Media pembelajaran digunakan dalam rangka komunikasi dan interaksi guru dan siswa dalam proses pembelajaran; b. Media pembelajaran memiliki pengertian non-fisik yang dikenal sebagai software (perangkat lunak), yaitu kandungan pesan yang terdapat dalam perangkat keras yang merupakan isi yang ingin disampaikan kepada siswa pada proses belajar baik di dalam maupun di luar kelas; c. Media memiliki pengertian fisik yang dewasa ini dikenal sebagai hardware (perangkat keras), yaitu suatu benda yang dapat dilihat, didengar, atau diraba dengan panca indera; dan d. Media pembelajaran dapat digunakan secara massal (misalnya: radio, televisi), kelompok besar dan kelompok kecil (misalnya: film, slide, video, OHP), atau perorangan (misalnya: buku, komputer, radio tape, kaset, dan video recorder).

\section{Tujuan dan Manfaat Media Pembelajaran}

Tujuan media pembelajaran sebagai alat bantu pembelajaran, adalah sebagai berikut: a. Mempermudah pembelajaran di kelas; b. Meningkatkan efisiensi proses pembelajaran; c. Menjaga relevansi antara materi pelajaran dengan tujuan belajar, dan; d. Membantu konsentrasi pembelajar dalam proses pembelajaran ${ }^{47}$. Sedangkan Nana Sudjana dan Ahmad Rivai ${ }^{48}$ memaparkan manfaat media pembelajaran sebagai alat

46 Cecep Kustandi dan Bambang Sutjipto. (2011). Media Pembelajaran Manual dan Digital. Bogor: Ghalia Indonesia. hlm. 10

47 Sanaky. Media Pembelajaran, Buku Pegangan Wajib Guru dan Dosen. hlm: 4.

48 Nana Sudjana dan Ahmad Rivai. (2001). Media Pengajaran. Bandung: Sinar Baru Algensindo. hlm. 2. bantu dalam proses pembelajaran adalah sebagai berikut: a. Pengajaran lebih menarik perhatian pembelajar sehingga dapat menumbuhkan motivasi belajar; $b$. Bahan pengajaran akan lebih jelas maknanya, sehingga dapat lebih dipahami pembelajar, serta memungkinkan pembelajar menguasai tujuan pengajaran lebih baik; c. Metode pembelajaran bervariasi, tidak semata-mata hanya komunikasi verbal melalui penuturan katakata lisan pengajar, pembelajar tidak bosan, dan pengajar tidak kehabisan tenaga, apalagi bila guru mengajar untuk setiap jam pelajaran; d. Pembelajaran lebih banyak melakukan kegiatan belajar, sebab tidak hanya mendengarkan penjelasan dari pengajar saja, tetapi juga aktivitas lain yang dilakukan seperti: mengamati, melakukan, mendemonstrasikan, dan lain-lain.

Selanjutnya Hujair AH. Sanaky ${ }^{49}$ memaparkan manfaat media pembelajaran bagi pengajar dan pembelajar sebagai berikut:

a. Manfaat media pembelajaran bagi pengajar, yaitu: 1) Memberikan pedomannya dan arah untuk mencapai tujuan; 2) Menjelaskan struktur dan urutan pengajaran secara baik; 3) Memberikan kerangka sistematis mengajar secara baik; 4) Memudahkan kendali pengajar terhadap materi pelajaran; 5) Membantu kecermatan, ketelitian dalam penyajian materi pelajaran; 6) Membangkitkan rasa percaya diri seorang pengajar; dan 7) Meningkatkan kualitas pengajaran.

b. Manfaat media pembelajaran bagi pembelajar, yaitu: 1) Meningkatkan

49 Sanaky. Media Pembelajaran, Buku Pegangan Wajib Guru dan Dosen. hlm. 5. 
motivasi belajar pembelajar; 2) Memberikan dan meningkatkan variasi belajar pembelajar; 3) Memberikan struktur materi pelajaran dan memudahkan pembelajar untuk belajar; 4) Memberikan inti informasi, pokok-pokok, secara sistematik sehingga memudahkan pembelajar untuk belajar; 5) Merangsang pembelajar untuk berpikir dan beranalisis; 6) Menciptakan kondisi dan situasi belajar tanpa tekanan; dan 7) Pembelajar dapat memahami materi pelajaran dengan sistematis yang disajikan pengajar lewat media pembelajaran.

\section{Kriteria dan Pertimbangan Pemilihan Media Pembelajaran}

Dalam memilih media pembelajaran untuk kepentingan pembelajaran sebaiknya memperhatikan kriteria sebagai berikut: a. Ketepatan dengan tujuan pengajaran, artinya media pembelajaran dipilih atas dasar tujuan-tujuan instruksional yang telah ditetapkan. Tujuan-tujuan instruksional yang berisikan unsur pemahaman, aplikasi, analisis dan sintesis lebih memungkinkan digunakannya media pembelajaran; $b$. Dukungan terhadap isi bahan pelajaran, artinya bahan pelajaran yang sifatnya fakta, prinsip, konsep dan generalisasi sangat memerlukan bantuan media pembelajaran agar lebih mudah dipahami siswa; c. Kemudahan memperoleh media, artinya media yang diperlukan mudah diperoleh, setidak-tidaknya mudah dibuat oleh guru pada waktu mengajar. Media grafis umumnya dapat dibuat guru tanpa biaya yang mahal, di samping sederhana dan praktis penggunaannya; d. Keterampilan guru dalam menggunakannya, apapun jenis media pembelajaran yang diperlukan, syarat utama adalah guru dapat menggunakannya dalam proses pembelajaran. Nilai dan manfaat yang diharapkan bukan pada medianya, tetapi dampak dari penggunaan oleh guru pada saat terjadinya interaksi belajar siswa dengan lingkungannya; e. Tersedia waktu untuk menggunakannya, sehingga media pembelajaran tersebut dapat bermanfaat bagi siswa selama pembelajaran berlangsung; dan f. Sesuai dengan taraf berpikir siswa, memilih media untuk pendidikan dan pengajaran harus sesuai dengan taraf berpikir siswa, sehingga makna yang terkandung di dalamnya dapat dipahami oleh para siswa. ${ }^{50}$

Senada dengan Nana Sudjana dan Ahmad Rivai, Azhar Arsyad ${ }^{51}$ menyampaikan bahwa kriteria pemilihan media pembelajaran bersumber dari konsep bahwa media pembelajaran merupakan bagian dari sistem instruksional secara keseluruhan. Untuk itu, ada beberapa kriteria yang patut diperhatikan dalam memilih media pembelajaran, yaitu:

a. Sesuai dengan tujuan yang ingin dicapai. Media pembelajaran dipilih berdasarkan tujuan instruksional yang telah ditetapkan secara umum mengacu kepada salah satu gabungan dari dua atau tiga ranah kognitif, afektif, dan psikomotor;

b. Tepat untuk mendukung isi pelajaran yang sifatnya fakta, konsep, prinsip, atau generalisasi.

c. Praktis, luwes, dan bertahan. Jika tidak tersedia waktu, dana, dan sumber daya lainnya untuk

50 Nana Sudjana dan Ahmad Rivai. (2001). Media Pengajaran. Bandung: Sinar Baru Algensindo. hlm. 4-5.

51 Azhar, Arsyad. (2004). Media Pembelajaran. Jakarta: Raja Grafindo Persada. hlm. 75-76. 
memproduksi, tidak perlu dipaksakan. Media yang mahal dan memakan waktu lama untuk memproduksinya bukanlah jaminan sebagai media pembelajaran yang terbaik. Kriteria ini menuntun guru atau instruktur memilih media pembelajaran yang ada, mudah diperoleh, atau mudah dibuat sendiri oleh guru. Media pembelajaran yang dipilih sebaiknya dapat digunakan di mana pun dan kapan pun dengan peralatan yang tersedia di sekitarnya, serta mudah dipindahkan dan dibawa kemana-mana;

d. Guru terampil menggunakannya. Ini merupakan salah satu kriteria utama. Apapun jenis media pembelajaran, guru harus mampu menggunakannya dalam proses pembelajaran. Nilai dan manfaat media pembelajaran amat ditentukan oleh guru yang menggunakannya;

e. Pengelompokan sasaran. Media pembelajaran yang efektif untuk kelompok besar belum tentu sama efektifnya jika digunakan pada kelompok kecil atau perorangan;

f. Mutu teknis. Pengembangan visual baik gambar maupun fotograf harus memenuhi persyaratan teknis tertentu. Misal, pada visual dan slide informasi atau pesan yang ditonjolkan dan ingin disampaikan tidak boleh terganggu oleh elemen lain yang berupa latar belakang.

\section{Fungsi Media Pembelajaran}

Media pembelajaran, menurut Kemp dan Dayton $^{52}$ dapat memenuhi tiga fungsi

52 Kemp, J. E. dan Dayton, D. K. (1985). Planning and Producing Instructional Media (Fifth utama apabila media itu digunakan untuk perorangan, kelompok, atau kelompok pendengar yang besar jumlahnya, yaitu:

Fungsi memotivasi minat atau tindakan, media pembelajaran dapat direalisasikan dengan teknik drama atau hiburan. Hasil yang diharapkan adalah melahirkan minat dan merangsang para siswa atau pendengar untuk bertindak (turut memikul tanggung jawab, melayani secara sukarela, atau memberikan sumbangan material). Pencapaian tujuan ini akan mempengaruhi sikap, nilai, dan emosi.

Fungsi menyajikan informasi, media pembelajaran dapat digunakan dalam rangka penyajian informasi di hadapan sekelompok siswa. Isi dan bentuk penyajian bersifat amat umum, berfungsi sebagai pengantar, ringkasan laporan, atau pengetahuan latar belakang. Penyajian dapat pula berbentuk hiburan, drama, atau teknik motivasi. Ketika mendengar atau menonton bahan informasi, para siswa bersifat pasif. Partisipasi yang diharapkan dari siswa hanya terbatas pada persetujuan atau ketidaksetujuan mereka secara mental, atau terbatas pada perasaan tidak atau kurang senang, netral, atau senang.

Fungsi memberi instruksi, media berfungsi untuk tujuan instruksi di mana informasi yang terdapat dalam media itu harus melibatkan siswa baik dalam mental maupun dalam bentuk aktivitas yang nyata sehingga pembelajaran dapat terjadi. Materi harus dirancang secara lebih sistematis dan psikologis dilihat dari segi prinsip-prinsip belajar agar dapat menyiapkan instruksi yang efektif. Di samping menyenangkan, media pembelajaran harus dapat memberikan pengalaman yang menyenang- 
kan dan memenuhi kebutuhan perorangan siswa.

Sedangkan menurut Hujair AH. Sanaky $^{53}$, media pembelajaran berfungsi untuk merangsang pembelajaran dengan: a. menghadirkan obyek sebenarnya dan obyek yang langka; b. membuat duplikasi dari obyek yang sebenarnya; c. membuat konsep abstrak ke konsep konkret; d. memberi kesamaan persepsi; e. mengatasi hambatan waktu, tempat, jumlah, dan jarak; f. menyajikan ulang informasi secara konsisten, dan g. memberi suasana belajar yang tidak tertekan, santai, dan menarik, sehingga dapat mencapai tujuan pembelajaran.

Berdasarkan pembahasan fungsi media pembelajaran di atas dapat disimpulkan bahwa media pembelajaran yang digunakan dalam interaksi komunikasi pada proses belajar mengajar berfungsi sebagai sarana yang digunakan untuk menyalurkan pesan berupa materi pelajaran dari komunikator dalam hal ini guru kepada komunikan yaitu siswa dalam rangka mencapai tujuan pembelajaran yang sudah direncanakan. Melalui proses komunikasi, materi pelajaran dapat diterima, diserap, dihayati, dan diamalkan siswa.

\section{F. Penutup}

Interaksi komunikasi dalam proses belajar mengajar merupakan upaya untuk mengadakan interaksi edukatif dalam kegiatan pembelajaran, sehingga tujuan pembelajaran dapat tercapai dengan efektif dan efisien. Komunikasi pembelajaran adalah proses terjadinya jalinan hubungan edukatif antara guru dengan siswa dimana

53 Hujair AH. Sanaky. (2011). Media Pembelajaran, Buku Pegangan Wajib Guru dan Dosen. Yogyakarta: Kaukaba. hlm. 6. komunikasi yang dibangun berhasil guna dan saling mempengaruhi keadaan perasaan di antara mereka dalam rangka memberi kesempatan kepada siswa untuk mencapai prestasi yang diharapkan. Beberapa metode interaksi komunikasi pembelajaran yang dapat digunakan untuk membina tingkah laku belajar secara edukatif dalam berbagai peristiwa interaksi. Untuk menetapkan metode interaksi mana yang tepat, guru harus menetapkan lebih dahulu apakah sebuah metode dapat dikatakan baik, diperlukan adanya acuan yang bersumber pada faktor utama yang menentukannya yaitu "tujuan" yang akan dicapai. Untuk mengatasi hambatan-hambatan di dalam proses komunikasi pembelajaran diperlukan berbagai alat dan/atau media pembelajaran yang dapat berfungsi sebagai sarana yang digunakan untuk menyalurkan pesan. Dalam pembelajaran di kelas, sarana/fasilitas alat yang digunakan untuk memperlancar komunikasi pembelajaran disebut dengan media pembelajaran.

\section{Daftar Pustaka}

Ahira, Anne. (2013). Faktor-Faktor Penghambat Komunikasi Efektif. Tersedia: (on-line). http://www. anneahira.com/komunikasiefektif.htm.24 Maret 2013. pkl.12.23 AM.

Adler, R. B., and G. Rodman. (2006). Understanding Human Communication. $9^{\text {th }}$ ed. Oxford: Oxford University Press.

Arsyad, Azhar. (2004). Media Pembelajaran. Jakarta: Raja Grafindo Persada.

Daryanto. (2011). Ilmu Komunikasi. Bandung: Sarana Tutorial Nurani Sejahtera.

Diliani, S.N.A, Dita. (2002). "Kompetensi Komunikasi Guru Taman kanakKanak". "Tesis". Fakultas Ilmu Sosial dan Ilmu Politik. Pascasarjana Universitas Indonesia. 
Ena, Teda Ouda. (2003). Membuat Media Pembelajaran Interaktif dengan Piranti Lunak Presentasi. From: http://www.ialf.edu/kipbipa/papers/ Ouda Teda Ena.doc, Akses, Senin, 20/10/2003.

Emanuel, R. (2005). A Rationale for the Basic Course: Fundamentals of Oral Communication vs. Public Speaking. USA: Alabama State University.

Hamalik, Oemar. (1989). Media Pendidikan. Bandung: Citra Aditya Bakti.

Iriantara, Yosal dan Usep Syaripudin, (2013). Komunikasi Pendidikan. Bandung: Simbiosa Rekatama Media.

J. E., Kemp dan D. K., Dayton. (1985). Planning and Producing Instructional Media (Fifth Edition). New York: Harper \& Row Publishers.

Kamus Besar Bahasa Indonesia. (2012). Pusat Bahasa. Cetakan Keempat. Edisi Keempat. Jakarta: Departemen Pendidikan Nasional. Gramedia.

Kustandi, Cecep dan Sutjipto, Bambang. (2011). Media Pembelajaran Manual dan Digital. Bogor: Ghalia Indonesia.

Liliweri, Alo. (1997). Komunikasi Antar Pribadi. Bandung: Citra Aditya.

Maringka, N.E., Olivia. (2013). "Efektivitas Komunikasi Keluarga Pada AnakAnak Penggelut Dunia Modeling". (Studi Pada Masyarakat Di Kelurahan Bahu). Journal "Acta Diurna" Vol.I. No.I.

Mulyana, D. (2005). Ilmu Komunikasi Suatu Pengantar. Bandung: Remaja Rosdakarya.

Permana, Johar. (2013). Teknik Komunikasi Dalam Pelatihan, Diakses dari UPI.edu/Direktori/FIP/Jur.

Administrasi Pendidikan. Tersedia: (on-line). 24 Maret 2013, pkl. 13.40.

Richmond, P. V., J. S, Wrench, and J., Gorhan. (2009). Communication. Affect. and Learning in the Classroom. California: Creative Common.

Sadiman, S. Arief. (1990). Media Pendidikan. Pengertian. Pengembangan. dan Pemanfaatannya. Jakarta: Raja Grafindo Persada.
Pendidikan.

(1996). Media

Pengembangan dan Pemanfaatannya. Jakarta: Raja Grafindo Persada. hlm: 6.

Sanaky, AH, Hujair. (2011). Media Pembelajaran, Buku Pegangan Wajib Guru dan Dosen. Yogyakarta: Kaukaba.

Sharma. (2009). Importance of Soft Skills Development in Education. Diakses dari http:// schoolofeducators.com/ 2009/02/importance-of-soft-skills-

development-in-education/ diakses pada 6 April 2013.

Stephen W. Littlejohn dan Karen A. Foss. (2011). Teori Komunikasi. Jakarta: Salemba Humanika. Edisi. 9.

Sudjana, Nana dan Rivai, Ahmad. (2001). Media Pengajaran. Bandung: Sinar Baru Algensindo.

Tim Dosen FIP IKIP Yogyakarta. (1992). Bacaan Wajib Media Pembelajaran, Diktat, FIP IKIP. Yogyakarta.

Utama, Suprapti, dkk. (2005). Konsep Pengembangan Panduan Evaluasi Pengembangan Soft Skills Mahasiswa Melalui Proses Pembelajaran di Univarsitas Udayana. Tim PHK-I Universitas Udayana.

Uwes, Sanusi. (2003). Visi dan Pondasi Pendidikan (Dalam Perspektif Islam). Jakarta: Logos.

Wiryawan, Anitah, Sri dan Noorhadi Th. (1994). Strategi Belajar Mengajar. Universitas Terbuka.

H. Salim Bahreisy dan H. Salim Bahreisy. (1992). Terjamah Singkat Tafsir Ibnu Katsier Jilid VII. Surabaya: PT. Bina Ilmu. 